\title{
Kecak Touristic Performance in Uluwatu Temple: Its Aspects of Vocal Karawitan
}

\author{
I Putu Ikka Darmawan ${ }^{1}$, Ni Wayan Ardini², I Gede Mudana ${ }^{3}$ \\ 1,2Institut Seni Indonesia Denpasar, ${ }^{3}$ Politeknik Negeri Bali \\ Email: putuikkadharma@gmail.com ${ }^{1}$, niwayanardini17@gmail.com ${ }^{2}$, \\ gedemudana@pnb.ac.id ${ }^{3}$
}

\begin{abstract}
ABSTRAK
Penulis melakukan proses observasi, studi kepustakaan, dan wawancara dengan ketua Sanggar Karang Boma, Desa Pecatu untuk mendapatkan informasi yang terkait dengan pertunjukan Kecak di Pura Uluwatu. Keunikan kesenian Kecak ini terlihat pada penyajiannya yang menggunakan iringan suara manusia. Pengolahan melodi dan jalinan pola-pola cak sangat memerlukan pernafasan yang kuat. Nilai estetis dapat dilihat dari keutuhan dalam penyajian Kecak yang disajikan secara utuh dengan pola yang tersusun di dalam vokal Kecak tersebut dengan penonjolan teknik pengolahan vokal yang harmonis antara cak polos dan cak sangsih. Keseimbangan pada penyajian Kecak dilihat dari pengolahan melodi dan pola pengucapan cak yang seimbang secara dinamika dan tidak terjadi suatu yang dominan.
\end{abstract}

Kata kunci: kesenian, pariwisata, seni pertunjukan, karawitan vokal, kecak.

\section{ABSTRACT}

The writers conducted the process of observation, literature study, and interviews with the head of Karang Boma Studio, Pecatu Village to get information related to the Kecak performance at Uluwatu Temple. The uniqueness of this Kecak art can be seen in the presentation that uses human voice accompaniment. Processing melodies and interlocking cak patterns really requires strong breathing. The aesthetic value can be seen from the wholeness in the presentation of Kecak which is presented in its entirety with the patterns arranged in the Kecak's vowels by highlighting the harmonious vocal processing techniques between plain and sangsih cak. The balance in the presentation of Kecak is seen from the melody processing and cak pattern pronunciation that is dynamically balanced and does not occur as a dominant one.

Keywords: art, tourism, performing arts, vocal music, kecak.

\section{INTRODUCTION}

Tourism is a travel to a place or places with a reason to get satisfaction and enjoy the beauty contained in the places visited. It is explained that "broadly tourism can be interpreted as a trip from one place to another which is temporary, both carried out by individuals and groups to seek balance and happiness with the environment in social, cultural, natural and scientific dimensions "(Kodhyat, 1983 in Ruastiti, 2019: 10). 
Tourism is a combination of goods and service products, so both are very important needed and produced by the Bali tourism industry. Interaction between tourists as service users and hosts as service providers is needed in tourism activities (Ruastiti, 2019: 27). Art also plays an important role in tourism in Bali, especially performing arts. Artists and local people are involved in tourism and include opportunities to enjoy the economic benefits of tourism. Bandem (1996) states that, "since the advent of tourism, the creative motivation for creating performing arts in Bali has shifted from ritual offerings to offerings to tourism" (Ruastiti, 2019: 141).

Yudarta explained that, "from the various forms of cultural traditions that exist, Balinese performing arts is one form of art that developed in the city of Mataram and has a high potential if involved in the tourism industry" (Yudarta, 2016, https://jurnal.isidps.ac.id/index.php/mudra/article/view/247). Art as one of the elements contained in culture as a result of human creation is used as a tourist attraction in order to bring in foreign exchange for the country. Various arts that are presented for tourism, one of which is often encountered, such as performing arts which include musical/musical and dance which are used as tourist attractions or tourist attractions that are staged. Tourism and art are interrelated. This is because tourism is a place or place where the art is developed. The art is shown to tourists in order to introduce the culture that we have, for example the Kecak performance at Uluwatu Temple, which includes elements of musical art and dance.

Based on the relationship between arts and tourism are interrelated, thus the author wants to find out why Kecak art was chosen as the performing arts of tourism in Uluwatu Temple. So, in this case the writer conducted an interview process with the chairman of Karang Boma Studio, Pecatu Village to get information related to the Kecak performance at Uluwatu Temple. In addition, in this case the writer wants to examine the musical aesthetic elements found in the Kecak vocal presentation.

\section{RESEARCH METHODS}

The research material is Kecak art as a tourism performance art and analyzing the aesthetic elements of vocal music in Kecak art which is explained in accordance with the methods carried out. The method used is descriptive method with a qualitative approach. According to M. Djunaidi Ghony \& Fauzan Almanshur, the data collected is in the form of words, images, and not numbers. This is caused by the application of qualitative methods (Ghony and Almanshur, 2016: 34). Qualitative research approach 
is research that produces findings that cannot be achieved using statistical procedures or by means of quantification (Ghony and Almanshur, 2016: 25).

Observation is a data collection technique that requires researchers to go to the field to observe things related to space, place, time, actors, activities, objects, time, events, goals, and feelings (Ghony and Almanshur, 2016: 165). Observation was carried out in order to know firsthand by field plunge. This was done in order to be able to interact between researchers with the subjects. Observations were made at Uluwatu Temple on December 9, 2019 by meeting the figures associated with the study and visiting the object under study.

Interviews were conducted to find out and obtain accurate data directly obtained from sources related to the object under study. Interviews conducted in this study are qualitative interviews as explained by M. Djunaidi Ghony and Fauzan Almanshur (2016) that qualitative interviews are one technique for collecting data and information. The use of this method is based on two reasons namely, by interviewing researchers can explore not only what is known and experienced by the subject under study, but what is hidden deep within the subject of research and what is asked of the informants can cover things that are cross-time relating to the past, this time, and also the future (Ghony and Almanshur, 2016: 176). This interview was conducted with the chairperson of Karang Boma Studio, Desa Pecatu Adat.

Documentation is carried out to collect the necessary data. The data collected in the form of photographs and also data obtained from interviews and recording results conducted. M. Djunaidi Ghony and Fauzan Almanshur in the book "Qualitative Research Methodology" explained, the document is any written material or film that is not prepared because of a researcher's request while the record is every written statement compiled by a person or institution for the purpose of testing an event (Ghony and Almanshur, 2016: 199). The documents obtained in this study were in the form of photos of the objects under study, photos of interview activities, some recordings of the results of interviews, video recordings of performances, and also some notes of the results of interviews.

Literature study was conducted to obtain sources relating to the material to be examined from books relating to the Kecak art. This literature study is carried out in order to avoid plagiarism in studying the object under study as explained by Sumadi Suryabrata in the book "Research Methodology" that to obtain information about these various things one must conduct a literature review. Theories and concepts in general can be found in general reference sources, namely literature in the form of text books, encyclopedias, monographs, and the like and also special reference sources, namely 
literature in the form of journals, theses, research bulletins, dissertations, and others that contain research report (Suryabrata, 2010: 18). The literature obtained by researchers is, books relating to the art of Kecak and knowledge of Bali tourism.

\section{DISCUSSION}

Uluwatu Temple which is a sacred area for Hindus is also developed as one of the tourist attractions prepared for tourists visiting Bali. Uluwatu Temple, which is known by tourists from various countries, is starting to get busy every day. Uluwatu Temple began to be glimpsed by the tourists after several writers then told the charm of the beauty of this region through their writings scattered on the internet or other newspapers. This is very beneficial for Pecatu Indigenous Village as the Manager of Uluwatu Tourism Area to do other breakthroughs to encourage greater tourist growth.

The addition of tourist attractions to provide added value to the region, so that tourists who come to visit not only can observe Uluwatu Temple but also can directly touch and get to know the culture and art of Bali. Performing arts presented to tourists at Uluwatu Temple are "Kecak" art. According to I Wayan Dibia in his book Kecak Dari Ritual ke Teatrikal, that Kecak is an art performance tour that is quite old in general. Based on available documents, this acapella musical dance theater generally plays Ramayana with choir performers, all men who appeared in Gianyar around the early 1930s. Kecak which is often referred to as "Monkey Dance" has now become one of the main menus in the performing arts of tourism in Bali (Dibia, 2017: 1).

This Cak or Kecak was first created by dancers in Bedulu Village, Gianyar Regency who were ordered by Walter Spies. The group was asked to find a new type of Ramayana performance that was only accompanied by the Cak choir contained in the Sang Hyang Dedari dance. The developed guardian core is the basis of Cak which is a purely secular show that is played only for tourists (Bandem and deBoer, 2004: 220-221). This Kecak performance is an art performance in which there is vocal musical and dance art.

The author's observations when he watched the performance in the Uluwatu Temple area, namely, the Kecak performance at Uluwatu Temple was presented before sunset, because at that time the presentation with the sunset view was very beautiful. Many foreign and domestic tourists watch the Kecak performance and natural beauty at Uluwatu Temple. The Kecak performance was also filled with jokes made by dancers so that tourists did not get bored to watch the Kecak performance at Uluwatu Temple. As Kaeppler stated in Dibia's article in the book on Tourism Knowledge in Bali, 
that the form of presentation of the art of tourism shows prioritizes the value of entertainment and visual appeal rather than content that requires serious appreciation and reflection (Ruastiti, 2019: 142).

The development of tourism performance art, especially art in Uluwatu Temple, according to the explanation of I Made Astra as Chairman of Karang Boma Studio, was interviewed on December 9, 2019, that in developing Kecak art for tourism in Uluwatu Temple, a new package was made in the performance but did not leave the Kecak art tradition. The selection of the Kecak dance as a tourist attraction in this region is very appropriate in addition to the fact that Kecak is a dance that is so unique compared to other types of dances, it is also greatly aided by a very strategic stage location with interesting sights to be enjoyed by tourists. This is what then convinced the travel agents to start opening as wide as possible for the Kecak Dance tour package at Uluwatu Temple, which was strung together with several other tourist attractions.

The presence of the Kecak Dance attraction which is staged every day in the afternoon has succeeded in making a surge in tourist arrivals. Most tourists choose to visit the Temple at Uluwatu in the afternoon, in addition to the surrounding scenery and sunset, the presence of the Uluwatu Kecak Dance can also be another reason for tourists to choose a time to visit in the afternoon. I Made Astra explained that, according to data provided by local managers, the number of tourist visits has increased since the addition of the Kecak dance attraction at Uluwatu Temple, the average tourist visit to Uluwatu Temple before the existence of the Kecak Dance ranged from 700 people to 1,000 people every day, but since the Kecak dance has become a tourist attraction that can be enjoyed by tourists the surge in tourist arrivals ranges from 2500 people to 3000 people every day (an interview with I Made Astra on December 9, 2019).

\section{Kecak as Vocal Karawitan in Uluwatu Temple}

Vocal music is music that is presented/produced using human voices such as Kecak performances that are presented with human voice or vocals. Kecak performances are now often found in tourist attractions in Bali, one of which is Uluwatu Temple, Pecatu Village, Kuta Selatan District, Badung Regency, presented by dancers from Sanggar Karang Boma, Pecatu Village. The uniqueness of this Kecak art can be seen in the presentation that uses human voice accompaniment. Processing melodies and interlocking cak patterns really requires strong breathing.

The following are some of the Kecak vocal notations based on observations of the Kecak show at Uluwatu Temple. 


\section{Pengucapan Ketukan}

\section{|| Pung Pung Pung Pung Pung Pung Pung Pung \|}

\section{Pola Cak 3}

$\begin{array}{lll}\| \ldots C . C . C & \| & \text { Cak Polos } \\ \| . C \ldots C . C . & \| & \text { Cak Sangsih } \\ \| \text { C.C.C.. } & \text { Cak Sanglot }\end{array}$

\section{Pola Cak 6}

$\begin{array}{clll} & \| C \ldots C \ldots C \ldots C . C . C \ldots & & \text { Cak Polos } \\ & \| . C \ldots C \ldots C \ldots C . C . C . & & \text { Cak Sangsih } \\ \text { Pola Cak } 5 & \| . C \ldots C \ldots C \ldots C \ldots C . & & \text { Cak Penyelah }\end{array}$

\section{Pola Melodi}

Melodi Bagian Awal Keluar Kecak

\|B S B $S$ \|

Melodi Bagian Kedua Kecak Dalam Posisi Duduk $\| Y I Y \cup Y E Y S$ ॥

Melodi Bagian Ketiga

$$
\text { ॥Y O Y A Y Y S } \|
$$

Melodi Keempat

$$
\|Y E Y S\|
$$

Melodi Kelima

$$
\|Y E Y A Y O Y S\|
$$

Melodi Keenam

$$
\text { "Y E Y O Y E Y S } \|
$$

Melodi Ketujuh

$$
\text { ॥3 } 73 \text { 3 S }
$$

In general, the melody in the presentation of Kecak is combined with the cak pattern so that harmony is established in its presentation. The initial melody part when seated is a given tempo that is fast tempo and when entering the cak pattern, the tempo is slowed. The melodic patterns presented vary according to the creativity and scenes that are released. The aesthetic value can be seen from the wholeness in the presentation of Kecak which is presented in full with the patterns arranged in the Kecak's vowels by highlighting harmonious vocal processing techniques between the 
plain and sangsih cak. The balance in the presentation of Kecak is seen from the melody processing and evaporation pattern of the dynamically balanced disk and does not occur as a dominant one.

\section{CONCLUSION}

Performing arts presented to tourists at Uluwatu Temple are "Kecak" art. This Kecak performance is an art performance in which there is vocal music and dance. Kecak Dance was chosen as a tourist attraction that will be prepared for tourists. The selection of the Kecak dance as a tourist attraction in this region is very appropriate in addition to the fact that Kecak is a dance that is so unique compared to other types of dances, it is also greatly aided by a very strategic stage location with interesting sights to be enjoyed by tourists. Tourist visits to Uluwatu Temple prior to the existence of the Kecak Dance ranged from 700 to 1000 every day, but since the Kecak dance has become a tourist attraction that can be enjoyed by tourists the surge in tourist arrivals ranges from 2500 to 3000 per day. The presence of the Kecak Dance attraction which is staged every day in the afternoon has succeeded in making a surge in tourist arrivals. Most tourists choose to visit the Temple at Uluwatu in the afternoon, in addition to the surrounding scenery and sunset, the presence of the Uluwatu Kecak Dance can also be another reason for tourists to choose a time to visit in the afternoon.

The uniqueness of this Kecak art can be seen in the presentation that uses human voice accompaniment. Processing melodies and interlocking cak patterns really requires strong breathing. The aesthetic value can be seen from the wholeness in the presentation of Kecak which is presented in full with the patterns arranged in the Kecak's vowels by highlighting harmonious vocal processing techniques between the plain and sangsih cak. The balance in the presentation of Kecak is seen from the melody processing and evaporation pattern of the dynamically balanced disk and does not occur as a dominant one.

\section{REFERENCES}

Bandem, I Made; Fredrik Eugene deBoer. 2004. "Kaja dan Kelod" Tarian Bali Dalam Transisi. Yogyakarta: Badan Penerbit ISI Yogyakarta.

Dibia, I Wayan. 2017. "KECAK" Dari Ritual ke Teatrikal. Yogyakarta: Kepel Press.

Djelantik, A.A.M. 1990. Pengantar Dasar Ilmu Estetika. Denpasar: Sekolah Tinggi Seni Indonesia Denpasar.

Ghony, M. Djunaidi; Fauzan Almanshur. 2016. Metode Penelitian Kualitatif. Jogjakarta: AR-RUZZ MEDIA.

Ruastiti, Ni Made. 2019. Pengetahuan Pariwisata Bali. Papua: Aseni. 
72 | I Putu Ikka Darmawan, Ni Wayan Ardini, I Gede Mudana

Yudarta, IG. 2016. "Potensi Seni Pertunjukan Bali Sebagai Penunjang Industri Pariwisata di Kota Mataram, Nusa Tenggara Barat". Mudra Jurnal Seni Budaya, 31(1). Retrieved from https: //jurnal.isidps.ac.id/index.php/mudra/article/view/247.

\section{Discography}

"Video Tari Kecak di Uluwatu Bali" (https: //www.youtube.com/watch?v=zj5Aucgvluo\&feature=share (Date accessed 10 December 2019). 